BIBLIOTIKA : Jurnal Kajian Perpustakaan dan Informasi

Volume 2 Nomor 2, 2018

Journal homepage : $\underline{\text { http://journal2.um.ac.id/index.php/bibliotika }}$

\title{
HUKUM BRADFORD PADA JURNAL ILMU SOSIAL DAN ILMU POLITIK
}

Rika Ayu Meilia ${ }^{*}$ Zulva Avidiansyah, DNA Iftinan

Sekolab Pascasarjana Universitas Gadjah Mada Yogyakarta

\begin{tabular}{|c|c|}
\hline $\begin{array}{l}\text { A R T I C L E } \\
\text { I N F O }\end{array}$ & A B S T R A C T \\
\hline $\begin{array}{l}\text { Article bistory: } \\
\text { Received: } 2 \text { May } 2018 \\
\text { Accepted: } 10 \text { May } 2018 \\
\text { Published: } 15 \text { Nov } 2018 \\
\text { Keyword: } \\
\text { Hukum Bradford, jurnal } \\
\text { ilmu sosial dan ilmu } \\
\text { politik, produktivitas } \\
\text { jurnal }\end{array}$ & $\begin{array}{l}\text { Jurnal Ilmiah sudah tidak diragukan lagi untuk kualitas informasinya } \\
\text { karena telah melalui proses seleksi sebelum diterbitkan. Akan tetapi, } \\
\text { produktivitas pada setiap jurnal perlu dihitung untuk mengetahui } \\
\text { bagaimana kualitas pada sebuah jurnal. Cara untuk menghitung } \\
\text { kualitas pada setiap jurnal dapat menggunakan hukum Bradford. } \\
\text { Artikel ini menjelaskan mengenai produktivitas jurnal Ilmu Sosial } \\
\text { dan Ilmu Politik Fakultas Ilmu Sosial dan Ilmu Politik Universitas } \\
\text { Gadjah Mada dari tahun } 2016 \text { hingga tahun } 2018 \text {.Setelah dilakukan } \\
\text { perhitungan dengan menggunakan hukum bradford, didapatkan hasil } \\
\text { bahwa total artikel sebanyak } 595 \text { dan } 425 \text { nama jurnal. Pembagian } \\
\text { pola distribusi tersebut sebanyak } 21 \text { jurnal dengan } 64 \text { judul artikel, } \\
\text { sebanyak } 82 \text { jurnal mencakup } 109 \text { judul artikel, dan sebanyak } 322 \\
\text { jurnal mencakup } 322 \text { judul artikel. Pembagian pola distribusi } \\
\text { tersebut sebanyak } 21 \text { jurnal mencakup } 64 \text { artikel, sebanyak } 82 \text { jurnal } \\
\text { mencakup } 109 \text { artikel, dan sebanyak } 322 \text { jurnal mencakup } 322 \\
\text { artikel. Hukum Bradford dapat digunakan untuk mengetahui } \\
\text { produktivitas jurnal dan dinyatakan valid untuk menemukan data set. } \\
\text { Dari perhitungan dan periode waktu terbit, dapat disimpulkan } \\
\text { bahwa Jurnal Ilmu Sosial dan Ilmu Politik Fakultas Ilmu Sosial dan } \\
\text { Ilmu Politik Univeristas Gadjah Mada dapat dikatakan memiliki } \\
\text { kualitas yang bagus dan merupakan salah satu jurnal yang penting } \\
\text { dibidang sosial dan politik. Dari hasil perhitungan tersebut, Jurnal } \\
\text { Ilmu Sosial dan Ilmu Politik merupakan jurnal yang dapat dijadikan } \\
\text { salah satu literatur dalam bidang ilmu sosial dan ilmu politik karena } \\
\text { produktivitasnya. }\end{array}$ \\
\hline
\end{tabular}

Jurnal ilmiah adalah sebuah publikasi yang diterbitkan secara berkala oleh suatu organisasi profesi atau institusi akademik yang memuat artikel- artikel yang merupakan produk pemikiran ilmiah secara empiris (artikel hasil penelitian) maupun secara logis (artikel hasil pemikiran) dalam bidang ilmu tertentu (Suryoputro, 2012).Isi dari jurnal ilmiah adalah artikel ilmiah yakni tulisan yang berisi laporan sistematis mengenai hasil kajian atau hasil penelitian yang disajikan bagi

\footnotetext{
* Corresponding author.

E-mail addresses: rikaayu94@mail.ugm.ac.id (Rika Ayu Meilia)
}

ISSN : 2579-3802 (Online) - BIBLIOTIKA : Jurnal Kajian Perpustakaan dan Informasi is licensed under Creative Commons Attribution-ShareAlike 4.0 International License (http://creativecommons.org/licenses/BY/4.0/). 
masyarakat ilmiah tertentu, yang merupakan audiens khusus dengan tujuan menyampaikan hasil kajian dan kontribusi penulis artikel kepada mereka untuk dipikirkan, dikaji kembali, dan diperdebatkan, baik secara lisan maupun secara tertulis (Suryoputro, 2012).

Menurut Wardikar (2013), “di antara berbagai sumber ilmiah yang ada, jurnal dianggap sebagai sumber informasi yang konten informasi di dalamnya memuat kebaharuan ilmu pengetahuan yang tinggi jika dibandingkan sumber informasi lainnya, mencakup informasi dan ide baru yang nantinya bisa diteliti kembali dengan objek penelitian yang berbeda. Di dalam jurnal dapat mencakup informasi mendalam tentang pemikiran mikro, perbandingan subjek, studi mendalam tentang subjek atau perkembangan baru dalam suatu subjek, dan masih banyak lagi yang lainnya". Peran dan fungsi jurnal ilmiah: (1) sarana komunikasi akademik antara para ilmuwan, (2) penyebaran atau desiminasi hasil-hasil penelitian, (3) pengembangan budaya akademik di perguruan tinggi, (4) sebagai penukaran informasi untuk menghasilkan ide-ide baru akan ilmu pengetahuan dan teknologi (Suryoputro, 2012).

Informasi yang terdapat pada jurnal ilmiah berisikan informasi yang berkualitas karena sebelum terbit setiap artikel ilmiah diseleksi terlebih dahulu. Akan tetapi tidak semua jurnal memiliki kualitas yang baik, adapula jurnal yang memiliki kualitas yang kurang baik. Maka dari itu diperlukan perhitungan produktivitas jurnal untuk mengetahui kualitas dari setiap jurnal. Perhitungan jurnal dapat dilakukan dengan menggunakan kajian bibliometrika dengan hukum bardford.Maka dari itu, artikel ini bertujuan untuk mengetahui produktivitas jurnal ilmu sosial dan ilmu politik milik fakultas ilmu sosial dan ilmupolitik Universitas Gadjah Mada

\section{TINJAUAN PUSTAKA \\ Hukum Bradford}

Bibliometrika yang mengkaji distribusi publikasi merupakan kajian kuantitatif terhadap literatur, hal ini ditandai dengan munculnya tiga dalil dasar bibliometrika, yaitu dalil Lotka untuk menghitung distribusi produktivitas berbagai pengarang, dalil Zipf untuk memberi peringkat kata dan frekuensi dalam literatur dan hukum Bradford untuk menentukan core journal suatu subjek tertentu. Hukum Bradford mencoba menjelaskan cara literatur sebuah subjek tersebar dalam jurnal subjek yang bersangkutan kemudian menghitung data Lubrication pada artikel jurnal menurut zona pertahun. Hukum Bradford menyatakan bahwa umumnya kebanyakan umunya subjek dikelompokkan dalam koleksi jurnal inti $1 / 3$ dari jumlah artikel yang ditemukan, 1/3 berikutnya menunjukkan kelompok jurnal menengah dan $1 / 3$ berikutnya menunjukkan kelompok jurnal yang luas (Mustafa, 2002).

Menurut Birger \& Jeppe, 2005 bahwa "Bradford telah menyiapkan daftar jurnal yang digunakan dalam bibliografi pada subjek Geofisika Terapan dan Pelumasan kemudian menyusunnya dalam urutan menurun. Dia mengidentifikasi tiga kelompok jurnal yang diberi peringkat berdasarkan produktivitas dari jurnal. Kelompok/zona pertama memiliki jumlah jurnal paling kecil namun sangat produktif yang disebut zona inti; kelompok/zona kedua memiliki jurnal yang cukup produktif dalam jumlah relatif besar; kelompok ketiga disebut zona produktif rendah yang memiliki sejumlah besar jurnal produktif yang rendah". Untuk membuktikan hukum Bradford, beberapa persyaratan harus diperhatikan, antara lain:

1. Subjek yang dipilih cukup sempit;

2. Kurun waktu penelitian; dan

3. Sumber data penelitian cukup lengkap.

Menurut Ishak, 2005 Hukum Bradford digunakan untuk "mengalisis produktivitas suatu set jurnal dalam subjek bidang tertentu dengan kurun waktu yang telah ditentukan. Hukum distribusi atau penyebaran Bradford mengindikasikan bahwa banyaknya artikel yang tersebar di dalam jurnal yang lebih sedikit dan sejumlah besar jurnal memiliki artikel yang lebih sedikit secara proporsional".

\section{METODE}


Dalam kajian Bradford ini metode yang digunakan dengan metode kuantitatif. Metode ini dilakukan dengan cara menghitung produktivitas suatu jurnal. Dalam kajian ini jurnal yang digunakan untuk dijadikan sebagai objek penelitian adalah jurnal Ilmu Sosial dan Ilmu Politik milik fakultas Ilmu Sosial dan Ilmu Politik Universitas Gadjah Mada.Jurnal yang akan diteliti adalah jurnal dari tahun 2016-2018. Jurnal Ilmu Sosial dan Ilmu Politik terbit 3 kali dalam satu tahun dan dalam setiap artikel terdapat 6 jurnal yang rutin terbit setiap tahunnya. Sehingga pada penelitian ini terdapat 54 artikel yang akan digunakan untuk bahan analisis sitasi.

\begin{tabular}{|c|c|c|c|c|}
\hline Tahun & Volume & Nomor & Total Publikasi & $\mathbf{\%}$ \\
\hline 2016 & 20 & 1 & 6 & 11,11 \\
\hline 2016 & 20 & 2 & 6 & 11,11 \\
\hline 2016 & 20 & 3 & 6 & 11,11 \\
\hline 2017 & 20 & 1 & 6 & 11,11 \\
\hline 2017 & 21 & 2 & 6 & 11,11 \\
\hline 2017 & 21 & 3 & 6 & 11,11 \\
\hline 2018 & 21 & 1 & 6 & 11,11 \\
\hline 2018 & 22 & 2 & 6 & 11,11 \\
\hline 2018 & 22 & 3 & 6 & 11,11 \\
\hline
\end{tabular}

Dari data diatas yang diperoleh dari Jurnal Ilmu Sosial dan Ilmu Politik dari tahun 20162018 terdapat 54 artikel yang telah dipilih dan dilakukan perhitungan dalam objek penelitian dan menentukan 3 zona jurnal.

\section{HASIL}

Pada jurnal Ilmu Sosial dan Ilmu Politik antara tahun 2016-2018 terdapat 425 nama jurnal. Terdapat 18 artikel dengan frekuensi 35 artikel pada tahun 2016-2018yang sering digunakan sebagai rujukan atau referensi. Pada baris yang memiliki frekuensi terbanyak kedua dengan jumlah frekuensi 7 kali adalah Jurnal Internasional Review of Administrative Sciences dan Jurnal Public Administraton Review. Selain itu, terdapat 4 jurnal dengan frekuensi sebanyak 5 kali yaitu jurnal Adminitration \& Society, European Journal of Political Research, The American Political Science Review dan The Pasific Review.Berikut adalah tabel yang memuat nama-nama jurnal beserta frekuensinya yang terdapat dalam Jurnal Ilmu Sosial dan Ilmu Politik tahun 20162018.

\begin{tabular}{|c|l|c|}
\hline No & \multicolumn{1}{|c|}{ Jurnal } & F \\
\hline 1 & Jurnal Ilmu Sosial dan Ilmu Politik & 35 \\
\hline 2 & International Review of Administrative Sciences & 7 \\
\hline 3 & Public Administration Review & 7 \\
\hline 4 & Administration \& Society & 5 \\
\hline 5 & European Journal of Political Research & 5 \\
\hline 6 & The American Political Science Review & 5 \\
\hline 7 & The Pacific Review & 5 \\
\hline 8 & American Journal of Sociology & 4 \\
\hline 9 & Asian Survey & 4 \\
\hline 10 & Bijdragen tot de Taal, Land, en Volkenkunde & 4 \\
\hline 11 & Comparative Political Studies & 4 \\
\hline 12 & Indonesia & 4 \\
\hline 13 & Journal of Current Southeast Asian Affairs & 4 \\
\hline 14 & Journal of Government and Politics & \\
\hline
\end{tabular}




\begin{tabular}{|c|c|c|}
\hline No & Jurnal & $\mathbf{F}$ \\
\hline 15 & Journal of Information Policy & 4 \\
\hline 16 & Journal of Leisure Research & 4 \\
\hline 17 & Organization Science & 4 \\
\hline 18 & Political Research Quarterly & 4 \\
\hline 19 & Administrative Science Quarterly & 3 \\
\hline 20 & British Journal of Political Science & 3 \\
\hline 21 & Bulletin of Indonesian Economic Studies & 3 \\
\hline 22 & Communication Research & 3 \\
\hline 23 & Contemporary Southeast Asia & 3 \\
\hline 24 & Entrepreneurship Theory and Practice & 3 \\
\hline 25 & International Political Science Review & 3 \\
\hline 26 & J\&MC Quarterly & 3 \\
\hline 27 & Journal of Business Venturing & 3 \\
\hline 28 & Journal of Health Services Research \& Policy & 3 \\
\hline 29 & Jurnal Ilmu Komunikasi & 3 \\
\hline 30 & Jurnal Kebijakan dan Manajemen PNS & 3 \\
\hline 31 & New Left Review & 3 \\
\hline 32 & New Media and Society & 3 \\
\hline 33 & Political Behaviour & 3 \\
\hline 34 & Population and Development Review & 3 \\
\hline 35 & Public Choice & 3 \\
\hline 36 & American Political Science Review & 2 \\
\hline 37 & Analisis CSIS & 2 \\
\hline 38 & Canadian Journal of Economics & 2 \\
\hline 39 & Comparative European Politics & 2 \\
\hline 40 & Critical Asian Studies & 2 \\
\hline 41 & Economic and Political Weekly & 2 \\
\hline 42 & European Political Science Review & 2 \\
\hline 43 & Family Relations & 2 \\
\hline 44 & International Journal of Communication & 2 \\
\hline 45 & International Journal of Social Welfare & 2 \\
\hline 46 & International Review of Administrative Science & 2 \\
\hline 47 & Journal of Broadcasting \& Electronic Media & 2 \\
\hline 48 & Journal of Contemporary Asia & 2 \\
\hline 49 & Journal of East Asian Studies & 2 \\
\hline 50 & Journal of Peace Research & 2 \\
\hline 51 & Journal of Personality and Social Psychology & 2 \\
\hline 52 & Journal of Communication & 2 \\
\hline 53 & Jurnal Komunikasi & 2 \\
\hline 54 & Jurnal Sosiologi Reflektif & 2 \\
\hline 55 & Jurnal Studi Komunikasi \& Media & 2 \\
\hline
\end{tabular}




\begin{tabular}{|c|c|c|}
\hline No & Jurnal & $\mathbf{F}$ \\
\hline 56 & Jurnal Transformasi Sosial WACANA & 2 \\
\hline 57 & Jurnal Transformative & 2 \\
\hline 58 & Jurnal Ultima Humaniora & 2 \\
\hline 59 & Leisure Sciences & 2 \\
\hline 60 & Management Decision & 2 \\
\hline 61 & Mass Communication and Society & 2 \\
\hline 62 & MIS Quarterly & 2 \\
\hline 63 & Party Politics & 2 \\
\hline 64 & Political Communication & 2 \\
\hline 65 & Political Psychology & 2 \\
\hline 66 & Procedia-Social and Behavioral Sciences & 2 \\
\hline 67 & Public policy and administration & 2 \\
\hline 68 & Regional Studies & 2 \\
\hline 69 & Social Policy \& Administration & 2 \\
\hline 70 & Telemedicine and E-Health & 2 \\
\hline 71 & The American Economic Review & 2 \\
\hline 72 & The American Review of Public Administration & 2 \\
\hline 73 & The International Journal of Press/Politics & 2 \\
\hline 74 & Transcultural Psychiatry & 2 \\
\hline 75 & Journal of Southeast Asian Studies & 2 \\
\hline 76 & Journal of Democracy & 2 \\
\hline 77 & Afr J Sports Med & 1 \\
\hline 78 & American Behavioral Scientist & 1 \\
\hline 79 & Development and Change & 1 \\
\hline 80 & Economic Record & 1 \\
\hline 81 & Academy of Management Review & 1 \\
\hline 82 & Albanian Journal Agric & 1 \\
\hline 83 & Al-Jāmi'ah: Journal of Islamic Studies & 1 \\
\hline 84 & American Behavioral Scientist & 1 \\
\hline 85 & American Journal of Industrial Medicine & 1 \\
\hline 86 & American Journal of Political Science & 1 \\
\hline 87 & American Sociological Review & 1 \\
\hline 88 & Annals of Tourism Research & 1 \\
\hline 89 & Annual Review of Political Science & 1 \\
\hline 90 & Annual Review of Psychology & 1 \\
\hline 91 & Annual Review Psychology & 1 \\
\hline 92 & Anthropological Quarterly & 1 \\
\hline 93 & Anthropology \& Education Quarterly & 1 \\
\hline 94 & Asia \& the Pacific Policy Studies & 1 \\
\hline 95 & Asia Pacific Journal of Education & 1 \\
\hline 96 & Asia Pacific Viewpoint & 1 \\
\hline
\end{tabular}




\begin{tabular}{|c|c|c|}
\hline No & Jurnal & $\mathbf{F}$ \\
\hline 97 & Asian Academy of Management Journal & 1 \\
\hline 98 & Asian Journal of Communication & 1 \\
\hline 99 & Asian Journal of Latin American Studies & 1 \\
\hline 100 & Asian Journal of Social Sciences & 1 \\
\hline 101 & Asian Social Science & 1 \\
\hline 102 & Asian Social Science Review & 1 \\
\hline 103 & Australian Journal of Asian Law & 1 \\
\hline 104 & Australian Journal of Emerging Technologies and Society & 1 \\
\hline 105 & BMC Medical Informatics and Decision Making & 1 \\
\hline 106 & BMC Public Health & 1 \\
\hline 107 & BMJ Open & 1 \\
\hline 108 & BMJ Journal & 1 \\
\hline 109 & Bold & 1 \\
\hline 110 & British Journal of Healthcare Management & 1 \\
\hline 111 & British Journal of Management & 1 \\
\hline 112 & California Management Review & 1 \\
\hline 113 & Cambridge Journal of Economics & 1 \\
\hline 114 & Canadian Journal of Administrative Sciences & 1 \\
\hline 115 & Canadian Journal of Communication & 1 \\
\hline 116 & Capitalism and Society, & 1 \\
\hline 117 & China Agricultural Economic Review & 1 \\
\hline 118 & China Report & 1 \\
\hline 119 & Clinical Medicine & 1 \\
\hline 120 & Cognition and Emotion & 1 \\
\hline 121 & Communication Methods and Measures & 1 \\
\hline 122 & Communication Theory & 1 \\
\hline 123 & Comparative Civilizations Review & 1 \\
\hline 124 & Computers in Human Behavior & 1 \\
\hline 125 & Conflict Resolution and Peer Mediation Journal & 1 \\
\hline 126 & Congress \& the Presidency & 1 \\
\hline 127 & Construction Management and Economics & 1 \\
\hline 128 & Contemporary Asia & 1 \\
\hline 129 & Corporate Communications: An International Journal & 1 \\
\hline 130 & Crisis & 1 \\
\hline 131 & Critical Asian Studies & 1 \\
\hline 132 & Croat Med Journal & 1 \\
\hline 133 & Cross-Cultural Gerontology & 1 \\
\hline 134 & Czech Sociological Review & 1 \\
\hline 135 & Development and Change & 1 \\
\hline 136 & Development and Society & 1 \\
\hline 137 & Developmental Psychology & 1 \\
\hline
\end{tabular}




\begin{tabular}{|c|c|c|}
\hline No & Jurnal & $\mathbf{F}$ \\
\hline 138 & Digital Enlightenment Yearbook 2012 & 1 \\
\hline 139 & Diogenes & 1 \\
\hline 140 & Duke Law Journal & 1 \\
\hline 141 & East West Journal of Economics and Business & 1 \\
\hline 142 & Economic Development Quarterly & 1 \\
\hline 143 & Economic Geography & 1 \\
\hline 144 & Economics & 1 \\
\hline 145 & Economics Letters & 1 \\
\hline 146 & Economy and Society & 1 \\
\hline 147 & Educational Management Administration \& Leadership & 1 \\
\hline 148 & Educational Researcher & 1 \\
\hline 149 & E-Health International & 1 \\
\hline 150 & Electoral Studies & 1 \\
\hline 151 & Electronic News & 1 \\
\hline 152 & Emergency Librarian & 1 \\
\hline 153 & Engineering Management Journal & 1 \\
\hline 154 & Entrepreneurship \& Regional Development & 1 \\
\hline 155 & Environment and Planning C: Government and Policy & 1 \\
\hline 156 & Environment and Urbanization & 1 \\
\hline 157 & Environmental and Planning & 1 \\
\hline 158 & Ethics Inf. Technol & 1 \\
\hline 159 & EURASIA Journal of Mathematics Science and Technology Education & 1 \\
\hline 160 & European Journal Crime and Policy Res & 1 \\
\hline 161 & European Journal of Communication & 1 \\
\hline 162 & European Journal of Political Economy & 1 \\
\hline 163 & European Planning Studies & 1 \\
\hline 164 & European Urban and Regional Studies & 1 \\
\hline 165 & Foreign Affairs & 1 \\
\hline 166 & Geoforum & 1 \\
\hline 167 & Geographical Review & 1 \\
\hline 168 & GeoJournal & 1 \\
\hline 169 & Geophilos & 1 \\
\hline 170 & Global Asia & 1 \\
\hline 171 & Global Journal of Human Social Science & 1 \\
\hline 172 & Global Media Journal - Canadian & 1 \\
\hline 173 & Health & 1 \\
\hline 174 & Hydrological Processes & 1 \\
\hline 175 & Ilmu Ushuluddin & 1 \\
\hline 176 & In Contemporary Southeast Asia: A Journal of International and Strategic Aff airs & 1 \\
\hline 177 & In Goettingen Journal of International Law & 1 \\
\hline 178 & Indonesian Journal on Geoscience & 1 \\
\hline
\end{tabular}




\begin{tabular}{|c|c|c|}
\hline No & Jurnal & $\mathbf{F}$ \\
\hline 179 & Industrial and Labor Relations Review & 1 \\
\hline 180 & Info Kajian Lembaga Administrasi Negara & 1 \\
\hline 181 & iNFORMATION An International Interdisciplinary Journal & 1 \\
\hline 182 & Information System Frontiers & 1 \\
\hline 183 & Informing Science Institute & 1 \\
\hline 184 & Innovation & 1 \\
\hline 185 & Int Environ Agreements & 1 \\
\hline 186 & Intercultural Education & 1 \\
\hline 187 & Interdisciplinary Approach to Economics and Sociology & 1 \\
\hline 188 & International Affairs & 1 \\
\hline 189 & International Communication Gazette & 1 \\
\hline 190 & International Critical Thought & 1 \\
\hline 191 & International Economic Review & 1 \\
\hline 192 & International Education Studies & 1 \\
\hline 193 & International Journal of Disaster Risk Science & 1 \\
\hline 194 & International Journal of Economics and Financial Issues & 1 \\
\hline 195 & International Journal Of Engineering And Computer Science & 1 \\
\hline 196 & International Journal of Environmental Research and Public Health & 1 \\
\hline 197 & International Journal of Industrial Ergonomics & 1 \\
\hline 198 & International Journal of Innovation in the Digital Economy & 1 \\
\hline 199 & International Journal of Innovation Management & 1 \\
\hline 200 & International Journal of Malay World and Civilisation (Iman) & 1 \\
\hline 201 & International Journal of Management and Commerce Innovations, & 1 \\
\hline 202 & International Journal of Manpower & 1 \\
\hline 203 & International Journal of Medical Informatics & 1 \\
\hline 204 & International Journal of Peace Studies & 1 \\
\hline 205 & International Journal of Policy Studies & 1 \\
\hline 206 & International Journal of Public Administration and Management Research & 1 \\
\hline 207 & International Journal of Social Science and Humanity & 1 \\
\hline 208 & International Journal of Sociology and Social Policy, & 1 \\
\hline 209 & International Journal of Urban and Regional Research & 1 \\
\hline 210 & International Journal Social Welfare & 1 \\
\hline 211 & International Organization & 1 \\
\hline 212 & International Regional Science Review & 1 \\
\hline 213 & Intervention & 1 \\
\hline 214 & Islam and Christian-Muslim Relations & 1 \\
\hline 215 & Issues in Informing Science and Information Technology & 1 \\
\hline 216 & ISTIQRA', Jurnal Penelitian Ilmiah P3M STAIN Datokarama Palu & 1 \\
\hline 217 & IT \& Society & 1 \\
\hline 218 & Japanese and International Economies & 1 \\
\hline 219 & Journal European Societies & 1 \\
\hline
\end{tabular}




\begin{tabular}{|c|c|c|}
\hline No & Jurnal & $\mathbf{F}$ \\
\hline 220 & Journal for Comparative Government and European Policy & 1 \\
\hline 221 & Journal für kritische Migrations-und Grenzregimeforschung & 1 \\
\hline 222 & Journal of Abnormal and Social Psychology & 1 \\
\hline 223 & Journal of Administration and Governance & 1 \\
\hline 224 & Journal of Adolescent Research & 1 \\
\hline 225 & Journal of Arts, Science \& Commerce & 1 \\
\hline 226 & Journal of Asian Studies & 1 \\
\hline 227 & Journal of Asia-Pacific Business & 1 \\
\hline 228 & Journal of Business and Technical Communication & 1 \\
\hline 229 & Journal of Business Ethics & 1 \\
\hline 230 & Journal of Care Sevices Management & 1 \\
\hline 231 & Journal of Change Management & 1 \\
\hline 232 & Journal of Children and Media & 1 \\
\hline 233 & Journal of Civil Society & 1 \\
\hline 234 & Journal of Cleaner Production & 1 \\
\hline 235 & Journal of Construction Engineering and Management & 1 \\
\hline 236 & Journal of Contemporary & 1 \\
\hline 237 & Journal of Contemporary China & 1 \\
\hline 238 & Journal of Contemporary Politics & 1 \\
\hline 239 & Journal of Economic Perspective & 1 \\
\hline 240 & Journal of Economics \& Management Strategy & 1 \\
\hline 241 & Journal of Educational Media, Memory, and Society Spring & 1 \\
\hline 242 & Journal of Elections, Public Opinion and Parties & 1 \\
\hline 243 & Journal of Feminist & 1 \\
\hline 244 & Journal of Feminist Philosophy & 1 \\
\hline 245 & Journal of Global Governance & 1 \\
\hline 246 & Journal of Global Information Management & 1 \\
\hline 247 & Journal of Happiness Studies & 1 \\
\hline 248 & Journal of Health Organization \& Management & 1 \\
\hline 249 & Journal of Health Psychology & 1 \\
\hline 250 & Journal of Human Rights & 1 \\
\hline 251 & Journal of Information Literacy & 1 \\
\hline 252 & Journal of Integrated Care & 1 \\
\hline 253 & Journal of Interdisciplinary Social and Community Studies & 1 \\
\hline 254 & Journal of Law, Policy and Globalization & 1 \\
\hline 255 & Journal of Law, Technology \& Policy & 1 \\
\hline 256 & Journal of Laws & 1 \\
\hline 257 & Journal of Management & 1 \\
\hline 258 & Journal of Management Studies & 1 \\
\hline 259 & Journal of Marketing & 1 \\
\hline 260 & Journal of Mass Communication and Society & 1 \\
\hline
\end{tabular}




\begin{tabular}{|c|c|c|}
\hline No & Jurnal & $\mathbf{F}$ \\
\hline 261 & Journal of Parks \& Recreation & 1 \\
\hline 262 & Journal of Physical Education, Recreation \& Dance & 1 \\
\hline 263 & Journal of Political Economy & 1 \\
\hline 264 & Journal of Political Ideologies & 1 \\
\hline 265 & Journal of Political Power & 1 \\
\hline 266 & Journal of Public Administration & 1 \\
\hline 267 & Journal of Public Procurement & 1 \\
\hline 268 & Journal of Research Administration & 1 \\
\hline 269 & Journal of Research on Technology in Education & 1 \\
\hline 270 & Journal of Risk Research & 1 \\
\hline 271 & Journal of Service Management & 1 \\
\hline 272 & Journal of Small Business and Enterprise Development & 1 \\
\hline 273 & Journal of Social and Political Theory & 1 \\
\hline 274 & Journal of Social Entrepreneurship & 1 \\
\hline 275 & Journal of Supply Chain Management & 1 \\
\hline 276 & Journal of the American Planning Association & 1 \\
\hline 277 & Journal of the Humanities and Social Sciences of Southeast Asia, & 1 \\
\hline 278 & Journal of Media and Communication & 1 \\
\hline 279 & Journalism \& Mass Communication Monographs & 1 \\
\hline 280 & Jurnal Acta Diurna & 1 \\
\hline 281 & Jurnal Administrasi Publik & 1 \\
\hline 282 & Jurnal Agrivita & 1 \\
\hline 283 & Jurnal Antropologi Sosial Budaya ETNOVISI & 1 \\
\hline 284 & Jurnal Aplikasi Teknik Sipil & 1 \\
\hline 285 & Jurnal Borneo Administrator & 1 \\
\hline 286 & Jurnal Dinamika Hukum & 1 \\
\hline 287 & Jurnal Ekonomi & 1 \\
\hline 288 & Jurnal Ekonomi dan Bisnis Indonesia (JEBI) & 1 \\
\hline 289 & Jurnal Fikrah & 1 \\
\hline 290 & Jurnal Global dan Strategis & 1 \\
\hline 291 & Jurnal Harmoni Multikultural \& Multireligius & 1 \\
\hline 292 & Jurnal Hidrolitan & 1 \\
\hline 293 & Jurnal Ilmiah Administrasi Publik & 1 \\
\hline 294 & Jurnal Ilmu Hukum & 1 \\
\hline 295 & Jurnal Ilmu Politik dan Ilmu Pemerintahan & 1 \\
\hline 296 & Jurnal Ilmu Politik dan Komunikasi Unikom & 1 \\
\hline 297 & Jurnal Informatika & 1 \\
\hline 298 & Jurnal Jom Fisip & 1 \\
\hline 299 & Jurnal Kebudayaan dan Politik Universitas Airlangga & 1 \\
\hline 300 & Jurnal Komunikasi Ikatan Sarjana Komunikasi Indonesia & 1 \\
\hline 301 & Jurnal Komunikasi UII & 1 \\
\hline
\end{tabular}




\begin{tabular}{|c|c|c|}
\hline No & Jurnal & $\mathbf{F}$ \\
\hline 302 & Jurnal Madani II & 1 \\
\hline 303 & Jurnal Makara, Sosial Humaniora & 1 \\
\hline 304 & Jurnal Mandatory & 1 \\
\hline 305 & Jurnal Masyarakat dan Budaya & 1 \\
\hline 306 & Jurnal Mimbar & 1 \\
\hline 307 & Jurnal Mimbar Hukum & 1 \\
\hline 308 & Jurnal Pemikiran Sosiologi & 1 \\
\hline 309 & Jurnal Penelitian Karet & 1 \\
\hline 310 & Jurnal Penelitian Politik & 1 \\
\hline 311 & Jurnal Perempuan & 1 \\
\hline 312 & Jurnal Sosial Nusantara (JSN) & 1 \\
\hline 313 & Jurnal Standarisasi & 1 \\
\hline 314 & Jurnal Studi Gender dan Anak & 1 \\
\hline 315 & Jurnal Studi Hubungan Internasional & 1 \\
\hline 316 & Jurnal TAPIs & 1 \\
\hline 317 & Jurnal Tasawuf dan Pemikiran Islam & 1 \\
\hline 318 & Jurnal Transformasi Administrasi & 1 \\
\hline 319 & Jurnal Unigal & 1 \\
\hline 320 & Jurnal Antropologi Indonesia, & 1 \\
\hline 321 & Jurnal Masyarakat Indonesia & 1 \\
\hline 322 & Jurnal Sejarah dan Budaya & 1 \\
\hline 323 & Jurnal UNISIA & 1 \\
\hline 324 & Kajian Malaysia & 1 \\
\hline 325 & Keperawatan Indonesia & 1 \\
\hline 326 & Knowledge Landscapes & 1 \\
\hline 327 & Korea Journal & 1 \\
\hline 328 & Labour & 1 \\
\hline 329 & Local Government Studies & 1 \\
\hline 330 & Makara Hubs-Asia & 1 \\
\hline 331 & Makara, Sosial Humaniora & 1 \\
\hline 332 & Management of Environmental Quality: An International Journal & 1 \\
\hline 333 & Management Science & 1 \\
\hline 334 & Masyarakat, Kebudayaan dan Politik & 1 \\
\hline 335 & Media and Communication & 1 \\
\hline 336 & Media Psychology & 1 \\
\hline 337 & Media Teknik Sipil & 1 \\
\hline 338 & Medical Anthropology Quarterly & 1 \\
\hline 339 & Michigan Journal of Race and Law & 1 \\
\hline 340 & MIMBAR, Jurnal Sosial dan Pembangunan & 1 \\
\hline 341 & Modern China & 1 \\
\hline 342 & Nordicom Review & 1 \\
\hline
\end{tabular}




\begin{tabular}{|c|c|c|}
\hline No & Jurnal & $\mathbf{F}$ \\
\hline 343 & Observasi Jurnal & 1 \\
\hline 344 & Online Psychology Journal & 1 \\
\hline 345 & Pacific Affairs & 1 \\
\hline 346 & Paramita & 1 \\
\hline 347 & Peace \& Change & 1 \\
\hline 348 & Peace \& Conflict Studies & 1 \\
\hline 349 & Perspectives in Public Health & 1 \\
\hline 350 & Perspektif & 1 \\
\hline 351 & Philosophy \& Social Criticism & 1 \\
\hline 352 & Politik Indonesia: Indonesian Political Science Review & 1 \\
\hline 353 & Population Research and Policy Review & 1 \\
\hline 354 & Pragmatics \& Cognition & 1 \\
\hline 355 & Procedia- Social and Behavioral Sciences & 1 \\
\hline 356 & Progress in Human Geography & 1 \\
\hline 357 & Prospects & 1 \\
\hline 358 & PS: Political Science and Politics & 1 \\
\hline 359 & Psychological Bulletin & 1 \\
\hline 360 & Psychological Review & 1 \\
\hline 361 & Psychological Science & 1 \\
\hline 362 & Psychology and Aging & 1 \\
\hline 363 & Psychology of Aesthetics, Creativity, and The Arts & 1 \\
\hline 364 & Public Administration & 1 \\
\hline 365 & Public Health Nutrition & 1 \\
\hline 366 & Public Performance and Management Review & 1 \\
\hline 367 & Public Personnel Management & 1 \\
\hline 368 & Public Relations Journal & 1 \\
\hline 369 & Quarterly Journal of Economics & 1 \\
\hline 370 & Regional Dynamics in a Decentralized Indonesia & 1 \\
\hline 371 & Reproductive Health Matters & 1 \\
\hline 372 & Research in Organizational Behaviour & 1 \\
\hline 373 & Research Journal of Social Sciences & 1 \\
\hline 374 & Research Policy & 1 \\
\hline 375 & Review of Agricultural Economics & 1 \\
\hline 376 & Review of Indonesian and Malaysian Affairs & 1 \\
\hline 377 & Review of Social Economy & 1 \\
\hline 378 & Review of World Economics & 1 \\
\hline 379 & Ritsumeikan Law Review & 1 \\
\hline 380 & Rural Sociology & 1 \\
\hline 381 & Schmalenbach Business Review & 1 \\
\hline 382 & Science \& Society & 1 \\
\hline 383 & Science Communication & 1 \\
\hline
\end{tabular}




\begin{tabular}{|c|c|c|}
\hline No & Jurnal & $\mathbf{F}$ \\
\hline 384 & Science Education International & 1 \\
\hline 385 & Sejarah dan Budaya & 1 \\
\hline 386 & Singapore Journal Tropical Geography & 1 \\
\hline 387 & Small Business Economics & 1 \\
\hline 388 & Smart and Sustainable Built Environment & 1 \\
\hline 389 & Sociological Theory & 1 \\
\hline 390 & Solidarity: Jurnal Transdisiplin Sosiologi, Komunikasi, dan Ekologi Manusia & 1 \\
\hline 391 & South East Asia Publication & 1 \\
\hline 392 & Southeast Asian Journal of Social Science & 1 \\
\hline 393 & State \& Local Government Review & 1 \\
\hline 394 & State Politics \& Policy Quarterly & 1 \\
\hline 395 & Technological Forecasting and Social Change & 1 \\
\hline 396 & Technovation & 1 \\
\hline 397 & Telematics \& Informatics & 1 \\
\hline 398 & TESL Canada Journal/Revue TESL Du Canada & 1 \\
\hline 399 & The Annals of the American Academy of Political and Social Science & 1 \\
\hline 400 & The Australian Journal of Chinese Affairs & 1 \\
\hline 401 & The China Quarterly & 1 \\
\hline 402 & The drawing board: An Australian review of public affairs & 1 \\
\hline 403 & The Economic Journal & 1 \\
\hline 404 & The Emergence of Social Enterprise & 1 \\
\hline 405 & The Indian Journal of Political Science & 1 \\
\hline 406 & The Information Society & 1 \\
\hline 407 & The Journal of American Academy of Business & 1 \\
\hline 408 & The Journal of Communication & 1 \\
\hline 409 & The Journal of Entrepreneurship & 1 \\
\hline 410 & The Journal of Political Economy & 1 \\
\hline 411 & The Journal of Politics & 1 \\
\hline 412 & The Journal of Social Media in Society & 1 \\
\hline 413 & The Journal of Technology Transfer & 1 \\
\hline 414 & The Pakistan Development Review & 1 \\
\hline 415 & The Qualitative Report & 1 \\
\hline 416 & The Review of Economics and Statistics & 1 \\
\hline 417 & The Service Industries Journal & 1 \\
\hline 418 & Theory and Society & 1 \\
\hline 419 & Therapeutic Recreation Journal & 1 \\
\hline 420 & Third World Planning Review & 1 \\
\hline 421 & Urban Policy and Research & 1 \\
\hline 422 & Wacana Jurnal Transformasi Sosial & 1 \\
\hline 423 & Work and Occupations & 1 \\
\hline 424 & World Development & 1 \\
\hline
\end{tabular}




\begin{tabular}{|c|c|c|}
\hline No & \multicolumn{1}{|c|}{ Jurnal } & F \\
\hline 425 & Youth \& Society & 1 \\
\hline
\end{tabular}

Untuk mempermudah proses penghitungan produktivitas jurnal, data pada tabel diatas dapat diringkas sebagai berikut,

\begin{tabular}{|c|c|c|}
\hline No & Jurnal & Artikel \\
\hline 1 & 1 & 35 \\
\hline 2 & 2 & 7 \\
\hline 3 & 4 & 5 \\
\hline 4 & 11 & 4 \\
\hline 5 & 17 & 3 \\
\hline 6 & 41 & 2 \\
\hline 7 & 349 & 1 \\
\hline
\end{tabular}

Dari tabel di atas, kemudian dilengkapi dengan perhitungan komulatif jurnal dan artikel yang dapat dilihat pada tabel berikut,

\begin{tabular}{|c|c|c|c|c|c|c|}
\hline No & Jurnal & Artikel & $\begin{array}{c}\text { Jumlah } \\
\text { Kumulatif } \\
\text { Jurnal }\end{array}$ & $\begin{array}{c}\text { Jumlah } \\
\text { Kumulatif } \\
\text { Artikel }\end{array}$ & $\begin{array}{c}\text { Ln } \\
\text { Komulatif } \\
\text { Jurnal }\end{array}$ & $\begin{array}{c}\text { Prosentase } \\
\text { Kumulatif } \\
\text { Artikel }\end{array}$ \\
\hline 1 & 1 & 35 & 1 & 35 & 0 & 5,88 \\
\hline 2 & 2 & 7 & 3 & 49 & 1,1 & 8,23 \\
\hline 3 & 4 & 5 & 7 & 69 & 1,95 & 11,6 \\
\hline 4 & 11 & 4 & 18 & 113 & 2,89 & 18,99 \\
\hline 5 & 17 & 3 & 35 & 164 & 3,56 & 27,56 \\
\hline 6 & 41 & 2 & 76 & 246 & 4,33 & 41,18 \\
\hline 7 & 349 & 1 & 425 & 595 & 6.05 & 100 \\
\hline & 425 & 595 & & & & \\
\hline
\end{tabular}

Untuk menentukan 3 zona Jurnal Ilmu Sosial dan Ilmu Politik dalam kurun waktu 3 tahun yaitu tahun 2016-2018, dilakukan dengan proses penghitungan pengganda bradford dengan menggunakan persamaan matematika seperti berikut ini,

$\gamma=0,5772$ (Euler's number)

$$
\mathrm{k}=\left(\mathrm{e}^{\gamma} \mathrm{Y}_{\mathrm{m}}\right)^{1 / \mathrm{p}}
$$

$\mathrm{e}=2,718$ (constant)

$\mathrm{e}^{\gamma}=1,781$

$\mathrm{p}=3$ zona

$\mathrm{Y}_{\mathrm{m}}=$ artikel dengan frekuensi terbanyak (68)

Maka $\mathrm{k}=(1,781 \cdot 35)^{1 / 3}$

$$
=3,91
$$

Kemudian mencari $\mathrm{r}_{0}, \mathrm{r}_{0}$ merupakan nomer jurnal di zona pertama

$\mathrm{r}_{0}=\mathrm{T}(\mathrm{k}-1) /\left(\mathrm{k}^{\mathrm{p}}-1\right)$, di mana $\mathrm{T}=$ total komulatif jurnal.

$=425(3,91-1) /\left(3,91^{3}-1\right)$

$=1.236,75 / 58,78$

$=21,04$

$=21$ 
Maka nilai jurnal pada masing-masing zona, dapat dihitung sebagai berikut

$\mathrm{r}_{0}=\mathrm{r}_{0} \times 1=21,04=21$

$\mathrm{r}_{1}=\mathrm{r}_{0} \times \mathrm{k}=21,04 \times 3,91=82,27=82$

$\mathrm{r}_{2}=\mathrm{r}_{0} \times \mathrm{k}^{2}=21.04 \times 3,91^{2}=321,67=322$

Pembagian zona jurnal dan artikel dapat dilihat pada tabel betiku,

\begin{tabular}{|c|c|c|c|c|}
\hline Zona & Artikel & Jurnal & Perbandingan & Pengganda Bradford \\
\hline Zona 1 & 164 & 21 & - & - \\
\hline Zona 2 & 109 & 82 & 3,3 & 3,9 \\
\hline Zona 3 & 322 & 322 & 15,33 & 3,93 \\
\hline Jumlah & 595 & 425 & & 3,92 \\
\hline
\end{tabular}

Berdasarkan hasil perhitungan di atas, di peroleh pengganda Bradfordnya yaitu 3,92.

Setelah diketahui pengganda bradfordnya, maka dapat dimasukkan kedalam persamaan bradfordnya yaitu sebagai berikut,

$$
\begin{gathered}
1: \mathrm{n}: \mathrm{n}^{2} \\
1: 3,92: 3,92^{2} \\
1: 3,92: 15,36
\end{gathered}
$$

\section{Verifikasi Hukum Bradford melalui Leimkuhler Model}

Pengujian bradford dilakukan untuk mengetahui hukum bradford ini diterima pada pengujian produktivitas jurnal Ilmu Sosial dan Ilmu Politik yang dihitung dalam kurun waktu 3 tahun yaitu tahun 2016-2018. Pengujian ini juga dibantu dengan menggunakan persamaan Model Leimkuhler.

Berikut persamaannya,

$$
\mathrm{R}(\mathrm{r})=\mathrm{a} \log (1+\mathrm{br})
$$

Di mana, $R(r)=$ komulatif artikel yang berkontribusi pada rangking jurnal 1, 2, 3.....r

$$
\begin{aligned}
& \mathrm{a}=\frac{\mathrm{Y} 0}{\log e k} \\
& \mathrm{~b}=\frac{(\mathrm{k}-1)}{r 0}
\end{aligned}
$$

Sebelum masuk pada persamaan Model Leimkuhler, dilakukan perhitungan nilai $\mathrm{Y}_{0}$ melalui persamaan berikut ini,

$$
\mathrm{Y}_{0}=\frac{A}{P}
$$

Keterangan:

$\mathrm{Y}_{0}=$ Nomer artikel di setiap zona bradford

$\mathrm{A}=$ jumlah komulatif artikel, yang diketahui dalam jurnal ilmu sosial dan ilmu politik dalam periode 3 tahun (2016-2018) sebanyak 595artikel

$\mathrm{P}=$ Zona Jurnal (sebanyak 3 zona)

Maka,

$\begin{aligned} Y_{0} & =\frac{595}{3} \\ & =198,33=198\end{aligned}$

Setelah nilai $\mathrm{Y}_{0}$ diketahui, kemudian menghitung nilai a dan $\mathrm{b}$, 


$$
\begin{aligned}
\mathrm{a} & =\frac{\mathrm{Y0}}{\log e k} \\
& =\frac{198}{\log e 3,91} \\
& =\frac{198}{0,59} \\
& =335.59 \\
\mathrm{~b} & =\frac{(\mathrm{k}-1)}{r 0} \\
\mathrm{~b} & =\frac{(3,91-1)}{21,04} \\
& =0,14
\end{aligned}
$$

Setelah nilai a dan b diketahui, kemudian masuk pada persamaan Model Leimkuhler.

$$
\begin{aligned}
\mathrm{R}(\mathrm{r}) & =\mathrm{a} \log \mathrm{e}(1+\mathrm{b} \cdot \mathrm{r}) \\
& =330 \log \mathrm{e}(1+0,14.425) \\
& =330 \log \mathrm{e}(1+59,5) \\
& =330 \log \mathrm{e}(60,5) \\
& =330.1,78 \\
& =597,35=595
\end{aligned}
$$

$$
R(r)=a \log (1+b \cdot r)
$$

Dari hasil perhitungan dengan rumus di atas, dapat diketahui bahwa nilai praduga dari komulatif artikel sebesar 595 dengan menggunakan komulatif jurnal (r) sebesar 425 dari Jurnal Ilmu Sosial dan Ilmu Politik dari tahun 2016 hingga 2018. Dilihat dari tabel yang selanjutnya, nilai komulatif artikel yang terletak pada komulatif jurnal (r) 425 sebesar 322. Hasil tersebut menunjukkan bahwa nilai praduga (597) dan nilai pengamatan (595) tidak jauh berbeda, hanya terdapat selisih 2 angka, maka dapat disimpulkan bahwa hukum bradford dapat diterima. Berikut ini gambar grafiknya 


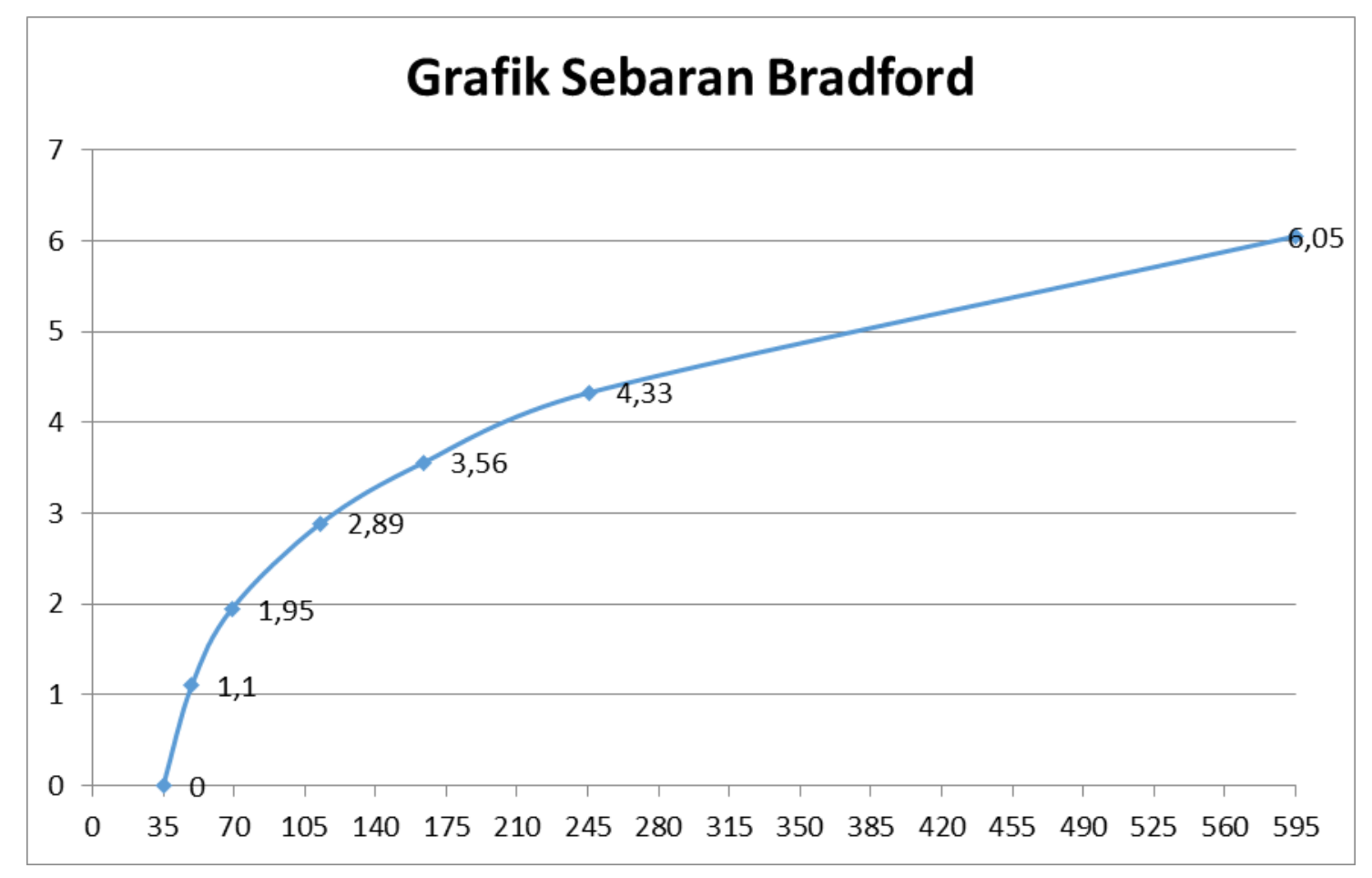

\section{SIMPULAN}

Berdasarkan perhitungan yang telah dilakukan di atas, dapat diketahui bahwa hasil perhitungan menunjukkan Jurnal Ilmu Sosial dan Ilmu Politik dari tahun 2016 hingga 2018 terdapat 595 total artikel dan terdapat 425 nama jurnal sesuai dengan pola distribusi bradford 1 : $\mathrm{n}: \mathrm{n}^{2}$. Pembagian pola distribusi tersebut sebanyak 21 jurnal mencakup 64 judul artikel, sebanyak 82 jurnal mencakup 109 judul artikel, dan sebanyak 322 jurnal mencakup 322 artikel. Hukum Bradford dapat digunakan untuk mengetahui produktivitas jurnal dan dinyatakan valid untuk menemukan data set. Dari hasil perhitungan dan periode waktu terbit, dapat disimpulkan bahwa Jurnal Ilmu Sosial dan Ilmu Politik Fakultas Ilmu Sosial dan Ilmu Politik Univeristas Gadjah Mada dapat dikatakan memiliki kualitas yang bagus dan merupakan salah satu jurnal yang penting dibidang sosial dan politik.

\section{DAFTAR PUSTAKA}

Birger, H., \& Jeppe, N. (2005). Bradford's law of scattering: Ambiguities in the concept of "subject".

Jatmiko, W. (2015). Panduan Penulisan Artikel Ilmiah. Jakarta: Universitas Indonesia.

Suryoputro, G. (2012). Menulis Artikel untuk Jurnal Ilmiah. Jakarta: Uhamka Press.

Wardikar, V. G. V. (2013). Application of Bradford's Law of Scattering to the Literature of Library \& Information Science: A Study of Doctoral Theses Citations Submitted to the Universities of Maharashtra, India. Library Philosophy and Practice, 1054.

Ishak. (2005). Analisis Bibliometrika terhadap Artikel Penelitian Penyakit Malaria di Indonesia Tahun 1970-April 2004 Menggunakan Database Online PubMed. Jurnal Studi Perpustakaan dan Informasi, 1(2), 17-18.

Mustafa. (2002). Mengenal hukum Bradford. Dalam Kumpulan Makalah Kursus Bibliometrika. Pusat Studi Jepang UI: Masyarakat Informatika Indonesia. 